\title{
Trayectorias artísticas-militantes: memoria y fotografía en el Museo de Arte y Memoria, de La Plata (Argentina) ${ }^{*}$
}

\author{
Florencia Larralde Armas*
}

Recibido: 15 de marzo de 2015

Evaluado: 20 de abril de 2015

Aceptado: 22 de abril de 2015

\section{Resumen}

El presente trabajo reconstruye y reflexiona sobre la construcción de un campo "artístico (fotográfico)-militante de la memoria" en Argentina. Inspirados en la teoría bourdiana, trabajamos en torno a cuatro trayectorias de artistas que confluyen en el espacio artístico del Museo de Arte y Memoria de La Plata. Con ello, logramos entender las distintas relaciones de alianza y solidaridad entre estos agentes y las instituciones en la conformación de un específico tipo de arte, correspondiente a los trabajos por la memoria de la última dictadura militar argentina.

Palabras clave: memoria, museo, fotografía, dictadura.

Este artículode investigación pertenece a mi tesis de maestría titulada Relatar con luz: el lugar de la fotografía en el Museo de Arte y Memoria de La Plata (2002- 2012), realizada en el marco de una beca doctoral de Consejo Nacional de Investigaciones Científicas y Técnicas (Conicet). Agradezco las sugerencias y comentarios realizados a este texto al grupo Cultura, arte y memorias del núcleo de Estudios sobre Memoria, Centro de Investigaciones Sociales, Instituto de Desarrollo Económico y Social (CIS-IDES). Cómo citar este artículo: Larralde Almas, F. (2015). Trayectorias artísticas-militantes: memoria y fotografía en el Museo de Arte y Memoria, de La Plata (Argentina). Hallazgos, 12(24), 63-87 (doi: http://dx.doi.org/10.15332/ s1794-3841.2015.0024.04).

** Magíster en Historia y Memoria, Universidad nacional de La Plata (Argentina); doctoranda en Ciencias Sociales, Universidad Nacional de La Plata (Argentina); becaria doctoral del Conicet. Pertenencia institucional al Centro de Investigaciones Sociales (CIS), Instituto de Desarrollo Económico y Social (IDES-Conicet) (Argentina). Correo electrónico: larraldeflor@yahoo.com.ar 


\section{Artistic-militants careers: memory and photography at the Museo de Arte y Memoria, La Plata (Argentina)}

\begin{abstract}
This work presents and reflects on the construction of an "art (photo) - Militant memory" field in Argentina. Inspired by the bourdiana theory, work around four artists paths that converge in the art space art Museo de Arte y Memoria de La Plata. With that, we understand the different relations of alliance and solidarity between these actors and institutions in shaping a specific type of art relevant to works by the memory of Argentina's military dictatorship.
\end{abstract}

Keywords: Memory, museum, photography, dictatorship.
Received: March 15, 2015

Evaluated: April 20, 2015

Accepted: April 22, 2015 


\title{
Trajetórias artísticas-militantes: memória e fotografia no Museu de Arte e Memória de La Plata (Argentina)
}

\begin{abstract}
Resumo
Recebido: 15 de março de 2015

O presente trabalho reconstrói e reflete sobre a construção de um campo "artístico (fotográfico) militante da memória" na Argentina. Inspirados na teoria do Pierre Bourdieu, abordamos quatro trajetórias de artistas que confluem no espaço artístico do Museu de Arte e Memória de La Plata. Com isso, logramos entender as diferentes relações de aliança e solidariedade entre estes agentes e as instituições em conformação de um específico tipo da arte, correspondente a os trabalhos pela memória da última ditadura militar na Argentina.
\end{abstract}

Palavras-chave: memória, museu, fotografia, ditadura. 
El arte es un estado de encuentro

Nicolás Bourriaud (2008)

\section{INTRODUCCIÓN}

En este artículo será analizada la construcción del campo "artístico (fotográfico)-militante de la memoria" en Argentina. Inspirados en la teoría bourdiana, será posible reconocer un campo específico de prácticas y acciones, correspondientes a un específico espacio social, que comienza a gestarse en plena dictadura y que alcanza su máxima expresión en la actualidad, en el marco de lo que se ha denominado institucionalización de la memoria ${ }^{1}$ (Longoni, 2010). Al final de este texto abordaremos el espacio social (Bourdieu) de la fotografía y la memoria en Buenos Aires y La Plata a partir de una institución concreta, que es el Museo de Arte y Memoria (MAM) de La Plata, ya que como sostiene Bourdieu "dado que hemos construido el espacio social, sabemos que estos puntos de vista, la palabra misma lo dice, son vistas tomadas a partir de un punto, es decir una posición determinada en el espacio social" (2000, p. 133). En nuestro caso, el lugar foco son Buenos Aires y La Plata, dos ciudades próximas que mantienen estrechas relaciones e intensos intercambios artísticos, sociales y culturales, ya que una es capital nacional y la otra provincial, de modo que el flujo de proyectos culturales y políticos es predominante en la región. Denominamos a este campo especifico como artístico-militante, ya que si bien puede tratarse de una imbricación de dos campos separados, los trabajos de la memoria

1 Desde 2003 y hasta nuestros días, en el marco de las políticas de memoria realizadas por el presidente Néstor Kirchner. conllevan producciones específicas desde diversos dispositivos artísticos que son exhibidos en el MAM, tanto como en espacios propios del arte (como galerías, salas de exposición y museos de arte), así como también en ex centros clandestinos de detención, museos y sitios de la memoria, organismos de derechos humanos, universidades, marchas en la vía pública, entre otros; de modo que los artistas participan de estos espacios simultáneamente retroalimentándolos. A continuación, se abordará detalladamente cada uno de estos puntos, teniendo como horizonte cuatro trayectorias $^{2}$ de fotógrafos exhibidos en el MAM. Se examinarás, por lo tanto, la constitución del campo haciendo foco en cuatro agentes: Marcelo Brodsky, Helen Zout, Gerardo Dell'Oro y Lucila Quieto, ya que son casos claves para entender las características de las distintas generaciones de fotógrafos que trabajan en sus obras sobre el tema de los desaparecidos por la última dictadura militar argentina. Entre ellos reconocemos a tres generaciones: la primera que podríamos denominar la generación de los desaparecidos, a la que pertenecen Brodsky y Zout; una generación intermedia (entre la generación de los desaparecidos y la de los hijos) a la que pertenece Dell'Oro, y la de los hijos, a la que pertenece Quieto.

2 La trayectoria es entendida por Bourdieu "como una serie de posiciones sucesivamente ocupadas por un mismo agente (o un mismo grupo) en un espacio en sí mismo en movimiento y sometido a incesantes transformaciones" (1997, p. 82). La trayectoria es comprensible "a condición de haber elaborado previamente los estados sucesivos del campo en el que ésta se ha desarrollado, por lo tanto el conjunto de las relaciones objetivas que han unido al agente considerado -por lo menos, en un determinado número de estados pertinentes del campo- al conjunto de los demás agentes comprometidos en el mismo campo y, enfrentados al mismo espacio de posibilidades" (Bourdieu, 1997, p. 82). 
Este artículo se centra en el análisis del MAM desde una mirada relacional ${ }^{3}$ (Bouriaud, 2008), ya que cuando el museo se instala en la ciudad de La Plata existía una realidad particular con respecto a la memoria y los derechos humanos en la región ${ }^{4}$. Entonces, en esta parte del análisis, intentaremos responder a los siguientes interrogantes: ¿qué situación se abre para el campo fotográfico de la memoria y los derechos humanos, dentro del espacio artístico?, ¿qué posibilita?, ¿qué alianzas y relaciones profesionales y militantes se generan?, ¿qué procesos de legitimación y validación se activan?, ¿qué tipos de trayectorias llegan al MAM?, ¿qué posibilidades se abren para los fotógrafos?

De acuerdo con la teoría bourdiana, concebimos a nuestros fotógrafos en cuanto agentes $^{5}$ que se posicionan dentro del espacio artístico; estas posiciones no son fijas y dependen de distintas relaciones de alian$\mathrm{za}^{6}$ y solidaridad entre ellos. A continuación nos ocuparemos de delinear y analizar la red de relaciones sociales (Bourdieu, 1995; Chartier, 1990) que se ponen en juego y que

3 Bourriaud plantea una teoría del arte desde una mirada relacional, y explica que si bien siempre se concibió al arte como un espacio independiente de la sociedad, la modernidad plantea un nuevo tipo de arte, un arte relacional, es decir "un conjunto de prácticas artísticas que toman como punto de partida teórico y práctico el conjunto de las relaciones humanas y su contexto social, más que un espacio autónomo y privativo" (2008, p. 142).

4 Trabajada por mí, en el artículo Larralde Armas (2014).

5 La noción de agente se "caracteriza por un yo como punto de unión de coerciones objetivas (el campo) y de determinaciones subjetivas (las estrategias elaboradas por el agente en función de su habitus, y cuyos fines tienden a coincidir con los fines inmanentes al campo), la noción de agente pone claramente de manifiesto la presencia de lo social (de disposiciones supra- individuales) en el corazón mismo de los pensamientos y comportamientos más íntimos y más conscientes" (Chauviré y Fontaine, 2008, p. 12).

6 Bourriaud (2008) nombra a este tipo de relaciones como "colaboracionismos" dentro del campo del arte y entre los artistas, pero acá se Ilamarán alianzas, para no entrar en confusiones con otras investigaciones sobre el período dictatorial argentino. atraviesan la actividad del MAM, que posee un circuito particular de interconexiones protagonizado, por un lado, por los artistas, los cuales comparten espacios de formación y exposición así como historias de vida que los unifican y, por el otro, con organismos y luchas por los derechos humanos. Una de nuestras trayectorias claves es la de la fotógrafa Helen Zout, debido a que ha tenido una actividad particular dentro del campo fotográfico, no solo como artista, sino también como gestora de diferentes espacios y especialmente como curadora fotográfica en el MAM durante el período 2008-2012.

A medida que nos sumerjamos en el análisis, será posible analizar y cotejar distintos aspectos que hacen al posicionamiento de ellos, por ejemplo en hitos clave en la historia de vida, espacios de formación y socialización, alianzas y relaciones profesionales y militantes, la cuestión generacional y la creación de nuevos espacios de exposición artística y sitios de memoria. En nuestro trabajo es interesante recuperar una pregunta realizada por Bourriaud (2008), en la que cuestiona cómo es posible comprender los comportamientos artísticos de una época y los modos de pensar que los sostienen, si no partimos de la situación misma de los artistas. A partir de esta línea de reflexiones, es posible preguntarnos cómo influyeron y repercutieron diferentes experiencias en relación con la represión ejercida por la última dictadura militar argentina, para dar lugar a una particular producción artística. Entre las experiencias que vivieron nuestros fotógrafos durante y a partir de la dictadura, se encuentran estados de persecución y exilio (exterior e interior), y pérdida de familiares.

Las luchas por el establecimiento y legitimación de memorias sobre la última dictadura 
militar penetraron en diferentes ámbitos, sujetos y prácticas, lo cual configuró una realidad particular que hace posible el trabajo del MAM y las prácticas de los fotógrafos y del campo de estudio organizado en torno a la producción y circulación de representaciones visuales. Desde esta perspectiva, y más allá de que existe un marco más amplio a estos casos, estas nociones nos ayudarán para vislumbrar aspectos de este campo artístico-militante, en el que el MAM en cuanto institución museística se instala como constructor y transmisor de sentidos del pasado, y los fotógrafos, en cuanto artistas, trabajan a partir de un lenguaje sensible en la construcción de identidades, elaboración de la historia y de memorias recientes.

\section{Alianzas y relaciones PROFESIONALES-MILITANTES EN EL CAMPO DEL ARTE}

\section{Exponer en el Museo de Arte y Memoria}

El $\mathrm{MAM}^{7}$ nace con el objetivo de transmitir y sensibilizar a la población en torno a los

7 El Museo de Arte y Memoria de La Plata fue fundado en 2002, por la Comisión Provincial por la Memoria (CPM). El proyecto surge de la necesidad de pensar al arte como un vehículo de transmisión, para pensar todos los temas y problemáticas sociales que trata la CPM. Desde su fundación y hasta 2012 el MAM estuvo bajo la dirección de Ana Cacopardo. Durante su gestión se expusieron muestras artísticas de diferentes disciplinas como plástica, fotografía, teatro, cerámica y cine; y muestras de producción propia de la CPM, donde por ejemplo se exhiben contenidos del archivo de la Dirección de Inteligencia de la Policía de la Provincia de Buenos Aires (DIPBA). Estos trabajos han sido realizados en conjunto con el MAM, muchas veces a cargo de la fotógrafa Helen Zout y con un montaje de carácter artístico. Al tratarse de un museo de "arte" y "memoria", el nive de expectativas no solo se amplía sino que se complejiza, requeriría de un estudio de recepción poder vislumbrar fehacientemente la perspectiva del visitante que llega al MAM, pero lo cierto es que esta relación entre arte y memoria dentro de este espacio aún es objeto de amplias reflexiones y debates. temas de historia reciente y sobre la agenda de derechos humanos que trabaja la Comisión Provincial por la Memoria; por eso durante los primeros años intenta convocar a los artistas que venían trabajando las temáticas del pasado reciente, la memoria y los derechos humanos, así como gestionar, encargar y producir obras de distintos temas que todavía los artistas no habían abordado.

El museo no tiene una política institucional explícita sobre qué tipo de obras o de artistas expone, pero la llegada de estos al museo va ligada a una red de relaciones de las que son parte los curadores y los artistas. Estas interrelaciones están basadas en un circuito artístico-militante en derechos humanos de los cuales todos forman parte en mayor o menor medida. A su vez, las temáticas por exhibir están directamente ligadas a las problemáticas que está tratando la CPM en ese momento. Por eso, como veremos a continuación, al principio había un interés de trabajar en torno a la represión, la memoria, quiénes eran los desaparecidos, y luego se van abriendo las temáticas hacia problemáticas más del presente, como la pobreza, los chicos de la calle, el gatillo fácil, las identidades de género, aunque siempre manteniendo problemáticas clásicas dentro del campo como la Guerra de las Malvinas, el exilio, las huellas de la represión, entre otras.

Durante los primeros años el MAM contó con la curaduría invitada de Florencia Battiti (actual curadora del Parque de la Memoria-Monumento a las Víctimas del Terrorismo de Estado) ${ }^{8}$. Puntualmente, la muestra

8 "En el caso del Parque de la Memoria, las exposiciones que allí se realizan desde 2010 son propuestas por la curadora y la directora al Consejo de Gestión para su aprobación. Dicho consejo se reúne 
de Lucila Quieto ${ }^{9}$ tuvo diferentes tipos de circulaciones dentro del circuito artístico, en la calle y actividades militantes, ya que también fue exhibida en el marco de su militancia en distintos ámbitos como fábricas recuperadas, actividades en la vía pública y marchas (cuestiones que serán detalladas más adelante). A su vez, el MAM le dio otra movilidad a su trabajo; por un lado, a través de la muestra instalada en el museo por invitación de Florencia Battiti y Laura Ponicio durante 2004; por otro lado, a través de las muestras itinerantes promovidas por el MAM, que le permitió llegar a diversas escuelas del país. En este sentido, Lucila considera que el MAM potenció su muestra a raíz de

[...] todo el trabajo que tienen ellos con las escuelas sobre todo en la provincia de Buenos Aires y todo lo que implica, no sólo La Plata y sus alrededores, entonces a mí eso me parece lo más interesante. Porque una vez me llamaron de una escuela, que queda en el conurbano bonaerense profundo, en un barrio súper humilde, tenían la muestra colgada y me invitaron a hablar, y yo de ninguna manera sino hubiera sido por la conexión del Museo y por el trabajo que ellos hacen en la Provincia, nunca hubiera llegado quizá a tener un intercambio de opiniones con pibes de esa escuela, y con los profesores, de

mensualmente y está compuesto por representantes de diez organismos de derechos humanos (los cuales no mantienen entre sí la misma presencia activa en las reuniones de consejo), funcionarios de las áreas de Educación, Espacio Público, Cultura y Derechos Humanos del Gobierno de la Ciudad Autónoma de Buenos Aires y un representante por la Universidad de Buenos Aires" (Battiti, 2013, p. 8).

9 Lucila Quieto (fotógrafa), nació en 1977, cuando su padre ya había sido secuestrado. Entre sus series más reconocidas se encuentran Arqueología de la ausencia (2001) y Filiaciones (2013). saber cómo laburaban. Me parece que lo potenció desde ese lado, me interesa más que los trabajos circulen en escuelas, en barrios, en ámbitos fuera de lo que es el mundo de los museos, me parece mucho más interesante ${ }^{10}$.

Quieto volvió a exponer en el MAM en el marco de muestras colectivas para las que fue convocada por el museo para crear obra. Una de ellas es la muestra de Oesterheld (2007) organizada por sus nietos, en la cual expuso una serie de collages y transfers sobre el personaje del Sargento Kirk ${ }^{11}$. Durante los primeros años de gestión, el MAM estableció relaciones con artistas y colectivos locales a través de propuestas puntuales, donde en conjunto armaron los materiales para exhibir, como las formas de montar las muestras ${ }^{12}$.

En este marco de artistas y curadores invitados, la fotógrafa Helen Zout comenzó a participar durante 2004 para incorporase al staff permanente del museo en 2008. Sus primeros trabajos tuvieron que ver con la curaduría de "Imágenes robadas, imágenes recuperadas" (julio de 2004-marzo de 2005), la primera muestra que trabaja con imágenes del archivo de la Dirección de Inteligencia de la Provincia de Buenos Aires. La incorporación de Helen Zout a este espacio abre

10 Entrevista a Lucila Quieto. Realizada por la autora el 6 de marzo de 2013.

11 Para un estudio sobre esta obra ver Blejmar (2013).

12 El MAM se ha vinculado con distintos colectivos e intelectuales para armar muestras y obras, como por ejemplo María Laura Guembe, Federico Lorenz, el colectivo de hijos e hijas de exiliados políticos de la última dictadura militar, artistas e investigadores de la Universidad de Chile, la Universidad de Barcelona, el Centro experimental Vigo, los colectivos ADDHES, Ala Plástica, Arde Minga, Grupo La Grieta, Grupo La Olla, Luli, Surcos- Praxis, Unidad Muralista Hermanos Tello (UMHT), Cátedra de Artes Combinadas y Procedimientos Transdisciplinares, Red de Teatro Comunitario Regional Sur, entre muchos otros. 
otro abanico de temáticas y de fotógrafos que llegan a la institución, entre ellos Gerardo Dell'Oro, que monta por primera vez su muestra Imágenes en la memoria. Como veremos en el siguiente apartado, Zout tiene una trayectoria particular en torno a la gestión de la fotografía en Buenos Aires y La Plata, cuyas relaciones con otros fotógrafos gestadas durante los años ochenta y noventa se reaviven al trabajar como curadora en el MAM.

Según Helen Zout, durante el tiempo que trabajó como curadora del MAM trajo "a los mejores fotógrafos de Argentina"13 al MAM, entre los que se encuentran (durante el período 2008-2012) Gerardo Dell'Oro, Juan Travnik, Sara Facio, Adriana Lestido, Marcos Adandía, Santiago Porter, Sebastián Szyd, Gabriel Díaz, Diego Paruelo y Gonzalo Mainoldi.

Sin embargo, antes del ingreso de Zout al MAM, ya se habían instalado un gran número de muestras fotográficas; cuestión que evidencia que la fotografía en sus diferentes vertientes y concepciones (artística o de autor, documental, fotoperiodismo) estuvo presente desde la fundación del $\mathrm{MAM}^{14}$. En

13 Entrevista a Helen Zout. Realizada por la autora el 18 de mayo de 2012.

14 Las muestras fotográficas instaladas en el período 2002-2007, previo a la llegada de Zout a la institución, son las siguientes: Buena Memoria, de Marcelo Brodsky (de mayo a julio de 2003), Treintamil y Secuelas, de Fernando Gutiérrez (de julio a diciembre de 2003), Arqueología de la ausencia, de Lucila Quieto (de marzo a julio de 2004), la Muestra colectiva: Pasado-Presente, de Ernesto Doménech, Lucila Quieto, Helen Zout, César López Osornio, Diana Dowek, Roberto Páez y Carlos Alonso (de septiembre de 2004 a marzo de 2005), Imágenes Robadas, Imágenes Recuperadas, producción CPM (de julio 2004 a marzo 2005), Muestra colectiva: cuatro miradas, cuatro fotógrafos, de Adriana Lestido, Santiago Hafford, Isabel De Gracia, Gian Paolo Minelli (de diciembre 2005 a marzo 2006), El lamento de los muros, de Paula Luttringer (de diciembre de 2005 a marzo de 2006), Muestra colectiva: Treinta años con memoria, de Rosana Fuentes, Lujan Funes y Magdalena Jitrik, Eduardo Gil, Helen Zout, Daniel Ontiveros, Horacio Zabala, Gabriel Kargieman, Riberto
2009 la revista Fotomundo titulaba "Museo de Arte y Memoria de La Plata, un espacio para la fotografía", y consideraba que "la fotografía tiene una importante presencia" (Fotomundo, 2009) en el museo. En el mismo sentido, Zout coincide en señalar que:

desde que yo entré se dio un valor enorme a la fotografía y se trajeron ciertos registros de los que considero los mejores fotógrafos argentinos, y hubiera traído más gente porque, digamos eso fueron los clásicos, pero después hay mucha gente más joven que está haciendo una obra increíble, y que daba hasta para hacer muestras colectivas de fotógrafos emergentes ${ }^{15}$.

Como sucedió a principios de los años ochenta, la figura de Helen Zout se destacó en la gestión del arte fotográfico, uniendo La Plata y Buenos Aires y con ello potenció el lugar del Museo de Arte y Memoria. Aunque como es posible ver a través del listado de muestras, la fotografía tuvo un peso fuerte en el museo desde sus inicios. En este sentido, es posible reconocer dos objetivos que se encuentran y enriquecen: el primero, el individual de Zout orientado a potenciar y gestionar sobre el campo fotográfico a través de su rol de curadora; y el segundo, el institucional del MAM enfocado en exponer y producir obra artística sobre la violación a los derechos humanos, a través de

Paez, León Ferrari, Liliana Parra, Juan Carlos Romero, Fernando Gutiérrez y Hugo Soubielle (de marzo a julio de 2006), Huellas de Desapariciones, de Helen Zout (de agosto a diciembre de 2006), Pequeños Piqueteros, de Xavier Kriscautzky (de agosto a diciembre de 2006), La credibilidad de lo fantástico, de Liliana Parra (de septiembre a diciembre de 2006), Rostros, fotos "sacadas" de la ESMA, de Víctor Basterra (de marzo a mayo de 2007), Desexiliando historietas (de mayo a junio de 2007) y Heridas y Prisión Vantaa, de Alfredo Srur (de junio a agosto de 2007).

15 Entrevista a Helen Zout, ya citada. 
un formato que tiene el poder multiplicador para poder exhibirse en otras localidades del país a través de las muestras itinerantes (en las que el dispositivo fotográfico se presenta en 23 de sus 25 muestras itinerantes).

\section{Antecedentes: espacios de formación y circuitos de exhibición}

Dentro de lo que es la producción fotográfica sobre la última dictadura Argentina, podemos marcar tres momentos temporales: el primero durante la dictadura, el segundo a fines de los años ochenta y el tercero desde mediados de los años noventa hasta nuestros días. No se trata de una cronología o de un ordenamiento, sino de indagar la forma como el campo fue constituyéndose transversalmente a lo largo de los años. Proponemos este acercamiento temporal, ya que la constitución del campo posee características específicas que podemos definir a partir de dos grandes estilos de la fotografía: por un lado, el artístico o de autor, y por el otro el fotoperiodístico ${ }^{16}$. Si bien ambos suelen confluir y retroalimentarse dentro de lo que es la lucha por la memoria, la verdad y la justicia, en el interior de lo que es el trabajo del MAM la línea que más se ha consolidado es la artística. Por eso perseguiremos ese rastro para dar cuenta de la configuración de este tipo de lenguaje visual.

\section{Espacios de formación en tiempos de dictadura}

Los fotógrafos que hoy trabajan sobre el tema de la memoria de la última dictadura militar argentina pueden dividirse en dos grandes generaciones: la de los

16 Para un estudio sobre el campo fotoperiodístico ver Gamarnik (2013). desaparecidos y la de los hijos. Con respecto a la primera, muchos de los autores que hoy exhiben obras fotográficas fueron perseguidos y vigilados por las fuerzas represivas, $\mathrm{y}$ eran estudiantes universitarios que militaban en distintas organizaciones, entre ellos podemos mencionar a Helen Zout, Adriana Lestido (Litvin, 22 de octubre, 2008), Marcelo Brodsky, Gustavo Germano ${ }^{17}$, Paula Luttringer (Fortuny, diciembre de 2011), Res

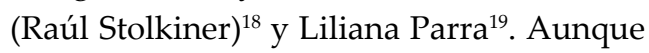
solo Luttringer es sobreviviente de un Centro Clandestino de Detención (CCD), durante este período todos ellos perdieron a familiares y amigos, cuestión que los llevó a vivir exilios interiores y exteriores. En este sentido, Zout se escondió en Buenos Aires y en Mar del Plata; Brodsky y Germano fueron a España; Luttringer, a Francia; Res, a México, y Liliana Parra, a Italia.

En este marco de persecución, muerte y exilio, se dieron los primeros momentos de aprendizaje de estos fotógrafos. Helen Zout (ver anexo Trayectorias) de la mano del fotógrafo Juan Travnik, con quien cursó sus primeros estudios en fotografía durante el tiempo que vivió en Buenos Aires en la clandestinidad a la edad de 19 años, y de quien dice: "tengo una historia de vida que me une con él" ${ }^{20}$. Juan Tranvik se ha convertido en un agente importante dentro de

17 Ver: http://ausencias-gustavogermano.blogspot.com.ar/.

18 Res (Raúl Stolkiner) es uno de los fotógrafos que se tuvieron que exiliar en el exterior, con la llegada de la dictadura. En su caso en México, donde comenzó a desarrollar su obra fotográfica. A su regreso a la Argentina se insertó en el campo artístico local. Y entre los años 1984- 1989 produjo la serie fotográfica "¿Dónde Están", una de las primeras obras fotográficas que abordan el tema de los desaparecidos de la última dictadura militar. (http://www.resh.com.ar/). Para un análisis sobre esta obra ver Fortuny (2009).

19 Entrevista a Liliana Parra. Realizada por la autora, el 11 de junio de 2011.

20 Entrevista a Helen Zout, ya citada. 
la escena fotográfica, ya que su trabajo lo vincula con una gran cantidad de artistas; por un lado, por los talleres que comenzó a dictar en tiempos de dictadura y que continúan hasta el día de hoy, siendo profesor de varias camadas de fotógrafos que actualmente se instalan en la escena fotográfica; por otro lado, porque desde 1998 dirige la Fotogalería del Teatro San Martín ${ }^{21}$, y ha sido parte de la organización de innumerables encuentros y muestras sobre fotografía.

Adriana Lestido comenzó sus estudios en fotografía en la Escuela de Arte y Técnicas Audiovisuales de Avellaneda en 1979, a un año de la desaparición de su marido. En tanto que Germano, Res, Parra y Brodsky realizaron sus estudios en distintas escuelas de los países que los albergaban. Puntualmente, Brodsky (ver anexto Trayectorias) inició sus estudios en el Centro Internacional de Fotografía, que dirigía Manuel Esclusa. Allí se introdujo al movimiento artístico de Barcelona junto a Joan Fontcuberta ${ }^{22}$, Humberto Rivas ${ }^{23}$ Y Tony Catany ${ }^{24}$. Desde el exilio se estaban gestando otros espacios de formación que marcarían el desarrollo

21 En referencia a series sobre la dictadura, se han expuesto en los últimos años las muestras Buena Memoria, de Marcelo Brodsky (1997), ADN, de Marín Acosta (2008), Santa Lucía. Arqueología de la violencia, de Diego Aráoz (2010), la muestra colectiva Espacios de Ausencia (2010), con Helen Zout entre sus fotógrafas, ESMA (2011) de Inés Ulanovsky, entre otros.

22 Actualmente Joan Fontcuberta (nacido en Barcelona, en 1955) es un renombrado artista, docente, ensayista, crítico y promotor de arte especializado en fotografía, con prolíferas producciones

23 Es otro de los fotógrafos que se exiliaron durante la dictadura, y si bien se encuentra radicado en Barcelona desde 1976, mantuvo contacto fluido con la producción local y ha exhibido sus trabajos en Buenos Aires.

24 Toni Catany (nacido en Mallorca, en 1942) es un fotógrafo considerado por la revista Life entre los 100 mejores fotógrafos del mundo. Se ha interesado por las técnicas fotográficas del siglo XIX que le han llevado a adquirir material fotográfico antiguo y a experimentar con técnicas muy diversas. del campo artístico actual a su retorno, ya que con la vuelta de la democracia, pero sobre todo a partir del vigésimo aniversario del golpe, en 1996, estos artistas comienzan a trabajar fotográficamente sobre su memoria, la ausencia y la dictadura.

En este marco, la formación de la fotógrafa Paula Luttringer fue posterior a la de sus compañeros que también estaban exiliados, pero la creación de sus series fotográficas sobre la dictadura se dieron en el mismo período que este grupo de fotógrafos. Es decir que Luttringer comienza sus estudios sobre fotografía a mediados de los años noventa, cuando luego de un largo exilio toma clases con Lestido y Travnik.

\section{Inicios de las salas y los espacios de exhibición especializados}

Como sostiene Usubiaga (2012), la fotografía artística o de autor fue consolidándose y abriéndose paso en las salas de exhibición artística durante los años ochenta a partir de los esfuerzos de los propios fotógrafos, ya que antes este tipo de arte era mantenido en los márgenes. Uno de los espacios claves que se instaló en la región fue la Fotogalería Omega creada por Helen Zout y Ataúlfo Pérez Aznar el 10 de octubre de 1980 en La Plata, ya que fue la "primer fotogalería especializada e independiente de la argentina" (Usubiaga, 2012, p. 239). Allí se realizaban muestras, talleres, conferencias, encuentros y publicaciones de textos teóricos sobre la disciplina.

La fotogalería ${ }^{25}$ fue un antecedente primordial para otros espacios fotográficos que se

\footnotetext{
25 La fotogalería continúa en funcionamiento y en el mismo espacio en calle diagonal $77 n^{\circ} 447$ (La Plata), Ataulfo Perez Aznar inauguró en 1991 el Centro de Fotografía Contemporánea (CFC). El mismo
} 
fundaron luego en Buenos Aires, de hecho cuando la muestra Los fotógrafos/autorretratos $^{26}$ se expuso en el Centro Cultural de la Ciudad de Buenos Aires (actual Centro Cultural Recoleta), en 1984, se trató de una reedición de la exhibición realizada en la Fotogalería Omega un año antes. Entre los expositores destacados estuvieron autores como Marcos López y Oscar Pintor ${ }^{27}$. También Marcelo Brodsky realizó una de sus primeras muestras allí en 1987, se trataba de la serie Aperturas, que luego también fue expuesta en Buenos Aires. Según la investigación de Viviana Usubiaga (2012), "la fotografía en sus diferentes vertientes y concepciones (artística, 'de expresión' o 'de autor', documental, publicitaria, fotoperiodismo) estuvo presente desde el primer momento de la nueva gestión" (2012, p. 202) del Centro Cultural de la Ciudad de Buenos Aires durante los primeros años de democracia. Según la autora, “la fotografía comenzó a ocupar espacios dedicados a las artes plásticas, donde antes era mantenida en los márgenes" (2012, p. 203).

consiste en salas de exposiciones, colecciones itinerantes, biblioteca especializada, colecciones de placas de vidrio y cámaras antiguas, entre otras cosas. En el CFC creó un banco de datos de La Fotografía Latinoamericana.

26 La muestra contenía trabajos de Enrique Abbate, Alfredo Baldo, Daniel Alberto Barraco, Carlos Capatto, Amado Becquer Casaballe, Enrique Cerveras, Horacio Clemente, Eduardo Comesaña, Horacio Coppola, Rubén Chiappini, Alicia D’Amico, Victor Dímola, Sara Facio, Hugo Gez, Eduardo Gil, Andy Goldstein, Gabriel Grioni, Eduardo Gossman, Sergio Guerrini, Juan José Guttero, Annemarie Heinrich, Martín Hoffman, Xavier Kriscautzky, Eduardo Longoni, Marcos López, Elias Mekler, Julie Méndez Ezcurra, Filiberto Mugnani, María Cristina Orive, Atáulfo Pérez Aznar, Roberto Piñeda, Oscar Pintor, Olkar Ramírez, Jorge Revsin, Mario Rodríguez, Anatole Saderman, Alfredo Sánchez, Ricardo Sanguinetti, Cristina Sarasa, Martín Siccardi, Ricardo Tegni, Juan Travnik, Gabriel Valansi, Raul Villalba, Dani Yanko, Helen Zout y Facundo de Zuviría (Usubiaga, 2012, p. 239).

27 Entrevista a Helen Zout, ya citada.
De acuerdo con su análisis, desde el restablecimiento de la democracia "no solo florecieron las muestras de fotografía, sino que se crearon diferentes ámbitos de reflexión sobre el lenguaje, grupos de estudio privados y seminarios públicos donde los fotógrafos iban a discutir sobre sus producciones con sus colegas" (Usubiaga, 2012, p. 204). En La Plata, otro de los espacios que se fundó fue el Núcleo de Autores Fotográficos (NAF) en mayo de 1984. Se trató de un grupo de reunión, discusión y debate de fotógrafos argentinos. Helen Zout se encontró nuevamente entre los miembros fundadores junto a Enrique Abbate, Alfredo Baldo, Hugo Gez, Eduardo Gil, Martín Glas, Eduardo Grossman, Juan J. Gutero, Marcos López, Gianni Mestichelli, Ataúlfo Pérez Aznar y Oscar Pintor. Para Helen, "el Núcleo fue una construcción de amigos o de vinculaciones aisladas que se solidificó. Nos juntábamos a todo, a charlar, a tomar vino, a comer, y a veces a charlar de fotografía. Creo que después de unos años que estuvimos juntos éramos más amigos que fotógrafos, que se juntaban a ver algunas fotos ${ }^{\prime 28}$.

En este periodo se comienza a gestar un entramado de relaciones que se pone en funcionamiento a la escena fotográfica de la época y se extiende hasta nuestros días, no solo en el marco del Museo de Arte y Memoria, sino también a través de una variada red de espacios y relaciones que funcionan en Buenos Aires y La Plata ${ }^{29}$, pero que

28 Entrevista a Helen Zout, ya citada.

29 Entre ellos la Fotogalería del Teatro San Martín, el Centro Cultural Recoleta, la Fotogalería Omega, la editorial La Marca, la Colección Fotógrafos Argentinos; así como la red de sitios y espacios de memoria que exhiben sus muestras, como el Museo de Arte y Memoria, el Centro Cultural Haroldo Conti, el Museo de la Memoria de Rosario, las distintas Comisiones Provinciales por la Memoria que funcionan en el país, El Parque de la Memoria, entre otros. 
igualmente logra llegar a distintos puntos del país.

Entre los objetivos del NAF se encontraba "valorizar a lo que se define como fotografía de autor", sin buscar "promover ningún estilo, tendencia o escuela determinada" (NAF, s. f.). En el manifiesto con el que se dieron a conocer públicamente, expusieron que:

[...] la escasa producción y la consecuente falta de difusión llevan a un empobrecimiento de las posibilidades de reflexión superadora. Faltan ámbitos adecuados para la discusión, crítica, investigación y docencia. Consideramos que la tarea de los fotógrafos es, en buena medida, incorporar definitivamente ese quehacer a nuestro patrimonio cultural a través de una continua y jerarquizada producción, la cual necesariamente debe ser proyectada en la sociedad, que es su destinataria natural.

Estos fotógrafos, hoy consagrados, estaban al margen de la exhibición artística de la época, y a raíz de estos nuevos espacios fueron instalándose en la escena local; de esta manera, se conviertieron en referentes de la fotografía nacional en la actualidad, y desempeñaron como artistas, docentes, curadores o generadores de hechos culturales.

En junio de 1986 el NAF realizó su primera muestra y con ella fue protagonista $-\sin$ quererlo- de uno de los primeros actos de censura en democracia. Se trató de una exposición llamada 1@Muestra del NAF, en la que sus integrantes exhibieron sus trabajos personales y el grupo una propuesta conceptual. La muestra contó con más de 120 fotos, que fueron instaladas en el que hoy es el Centro Cultural Borges, y donde entre 1982 y 1989 funcionó el Centro Cultural Islas Malvinas, dependiente de la Dirección Nacional de Artes Visuales. Allí fueron secuestradas 23 imágenes por la justicia, luego de que se realizara una denuncia por un particular, por "supuesta ofensa a la moral pública"; se trataba de fotos de desnudos, nueve fotos con autoría de Gianni Mestichelli, tres de Enrique Abbate y el resto de Pérez Aznar. La muestra siguió adelante sin esas fotos (se colocaron carteles en los espacios vacíos, para advertir al espectador del retiro de estas obras). La demanda no prosperó, pero las imágenes fueron "liberadas" recién un año después. El hecho fue repudiado por la mayoría de las instituciones abocadas al quehacer fotográfico.

Uno de los logros del grupo fue la participación de varios de sus miembros en la Semana Nacional de Fotografía en Ouro Preto, Brasil, en 1987, cuestión que permitió a diversos autores mostrar su trabajo en el extranjero. Finalmente, en 1988, el NAF organizó las Jornadas de Fotografía Buenos Aires-La Plata, que incluyeron exposiciones, talleres y mesas redondas, hecho que sentó precedentes para los innumerables festivales y encuentros que se organizaron luego ${ }^{30}$. Finalmente, sintiendo cumplidos buena parte de sus objetivos, el NAF decidió disolverse.

Gerardo Dell'Oro (ver anexo Trayectorias), al ser de una generación intermedia entre los desaparecidos y sus hijos, para 1984

30 Un ejemplo de ello fueron los Encuentros Abiertos de Fotografía (desde 1989, realizados hasta 1998). Más tarde los Encuentros se incorporaron al Festival de la Luz (desde el 2000, al presente), con ellos lograron posicionar a la fotografía a nivel nacional e internacional, incluyéndose dentro del mercado artístico. Para un análisis específico sobre esta cuestión ver Pérez Fernández (2011). 
tenía 18 años y comienza a estudiar en la Escuela de Arte y Técnicas Audiovisuales de Avellaneda, donde ya había cursado Lestido. Y si bien se ha dedicado más al fotoperiodismo también ha creado series artísticas sobre temas sociales y derechos humanos.

Durante los primeros años de democracia se crearon diferentes tipos de asociaciones y agrupaciones fotográficas ${ }^{31}$, que enriquecieron los debates, intercambios, experiencias y muestras fotográficas. Pérez Fernández (2011) categoriza a este tipo de iniciativas dentro de lo que define como los fotógrafos independientes, es decir, fotógrafos que estaban por fuera de la actividad fotoclubista ${ }^{32}$, que concentraba gran parte de la actividad hasta finalizada la dictadura. En este sentido, Usubiaga explica que:

[...] con el fin de la represión se abrieron canales para las imágenes antes vedadas. Muchos profesionales comenzaron a mostrar los trabajos que habían ocultado durante la dictadura, a los que se sumaron las producciones

31 Entre ellos podemos mencionar al Grupo de Fotógrafos (GUF) en 1983, al movimiento Fotografía Abierta en 1984, y al Centro de Estudios Fotográficos (CEF) en 1985. Pérez Fernández (2011) sostiene que, el antecedente más directo de estas agrupaciones fue el Consejo Argentino de Fotografía (CAF), creado en octubre de 1979, estaba dirigido por Eduardo Comesaña, Alicia D’Amico, Sara Facio, Andy Goldstein, Annemarie Heinrich, María Cristina Orive y Juan Travnik; Oscar Pintor y Julie Weiss actuaron como colaboradores. Entre sus objetivos se encontraban "reunir fuerzas dispersas que desde los 70 se identificaron con la fotografía independiente" (2011, p. 14).

32 De acuerdo con el estudio de Pérez Fernández (2011), para la década de los años setenta los fotoclubes ascendían a 143 dispersos en todo el país, y durante la dictadura su actividad no se vio prácticamente perturbada, ya que entre las normas elaboradas por la FAF (Federación Argentina de Fotografía) en 1973 quedaba explícitamente excluida la referencia a "temas que podían derivar en discusiones del tipo ideológico, lo que implicaba, en términos institucionales, un activo desentendimiento del contexto político. Ello, sumado a una estética limitada y encorsetada, hicieron de la fotografía fotoclubista una actividad cultural funcional a la política represiva que impuso la dictadura" (2011, p. 12). de los que volvieron del exilio. Ya no se vivía el peligro por circular con cámaras por la calle y ejercer la libertad del registro (2012, p. 204).

En simultáneo, en Buenos Aires se estaba desarrollando la apertura de nuevos espacios dependientes del estado, que dialogaban fluidamente con los espacios y artistas de La Plata, como la Fotogalería del Teatro Municipal General San Martín, con Sara Facio como su primera directora, en mayo de 1985. A principios de 1986 se formalizó el FotoEspacio dentro del Centro Cultural Ciudad de Buenos Aires (CCCBA), con Oscar Pintor como asesor fotográfico. Los propósitos fundacionales de FotoEspacio fueron la promoción de nuevos artistas, el rescate de los fotógrafos provincianos de principios de siglo y la realización de seminarios, talleres y conferencias. Entre los nuevos artistas que expusieron su obra se encuentra Marcelo Brodsky, quien montó Palabras, en 1986. A partir de 1988, su curaduría pasó a manos de Eduardo Gil, quien organizó muestras de Hugo Gez, Pintor, Julie Weisz, Dani Yanko, Gabriel Valansi, Daniel Ojeda y Facundo de Zuviría, entre otros. De las muestras colectivas también participaron Alfredo Baldo, Res (pseudónimo de Raúl Eduardo Stolkiner), Martín Glas, Elías Mekler y Mario Rodríguez.

En la conformación de este campo se dan dinámicas particulares de alianza y solidaridad entre los fotógrafos, ya que el objetivo común es hacer visible su trabajo e instalarlo en la escena artística nacional. Para ello se dan roles como el de "artista/curador", inscriptos en diversas instituciones y muchas veces protagonizado por grupos de fotógrafos, cuyo trabajo ha sido imprescindible en 
determinar la exhibición de esta producción artística. A su vez, las muestras se han concebido como espacios de encuentro entre los artistas y su público, instalando nuevas temáticas de discusión.

Como fue posible observar, la figura de Helen Zout ocupa un lugar particular dentro del campo fotográfico, ya que desde su gestión durante los años ochenta comienza a hilvanar una red de profesionales que potenciarán y reposicionarán su trabajo dentro del MAM, ya no solo como artista sino también como una verdadera "emprendedora de memoria" (Jelin, 2002), por cuento participa en la lucha por construir, transmitir e institucionalizar una narrativa sobre la última dictadura militar argentina y sus consecuencias. En este sentido, la labor fotográfica y artística da lugar a una recomposición de la trama social, que había sido fracturada por la dictadura, ahora, caracterizada por lazos de solidaridad, alianza y compromiso militante en derechos humanos.

\section{EN TIEMPOS DE MEMORIA: LA MILITANCIA EN EL ARTE Y EL ARTE EN LA MILITANCIA}

Como hemos trabajado anteriormente (Larralde Armas, 2014b), a partir del vigésimo aniversario del golpe se dan dos etapas claves y claramente identificables. La primera desde mediados de los años noventa y la segunda a partir de 2003 hasta nuestros días. Cada una de estas etapas configura una matriz de intervención artístico-política diferente, ya que se expresan en distintos contextos: durante el primero sobre todo en la vía pública, en un contexto de luchas sociales encaradas por organismos de derechos humanos y otras asociaciones. En este sentido, la calle, las manifestaciones y espacios como escraches, fábricas recuperadas, escuelas y universidades se presentaron como lugares donde registrar y exhibir muestras y fotografías, a veces muy precariamente colgadas de hilos en las veredas. En el segundo momento, a estos espacios se les suman lugares más institucionalizados como sitios, museos y archivos de la memoria, gestionados por organismos de derechos humanos, de modo que el campo fotográfico y el militante confluyen potenciándose, y se generan así nuevos proyectos, estrategias de exhibición y registro.

En este sentido, el caso de Lucila Quieto (ver anexo Trayectorias), así como otros hijos de desaparecidos que se han desarrollado en el campo fotográfico y audiovisual, como Clara Rosson, Inés Ulanovsky, Albertina Carri, Nicolás Prividena, entre muchos otros, es ejemplo de una nueva generación en la cual la militancia y el arte se dan en simultáneo y se retroalimentan. Lucila militó en Hijos ${ }^{33}$ desde 1995 hasta 2001. Durante esos años participó en varias comisiones: un corto tiempo en la de escraches, trabajando junto a la gente del GAC y Etcétera, realizando la volanteada y pintada en los días previos. Más tarde estuvo en la comisión de barrios, y trabajó un tiempo en el barrio que se había conformado en Villa Fiorito luego de una toma de tierras; allí armaron clases de apoyo, talleres de plástica, merienda y construcción de casillas. Durante ese tiempo, Lucila estudiaba en la Escuela de Fotografía Creativa de Andy Goldstein ${ }^{34}$ (entre 1996 y 2001). En paralelo, formó par-

33 Es una agrupación de hijos de desaparecidos que se conformó en el año 1995

34 Otra de la fotógrafas que ha trabajado el tema de desaparecidos y que se formó con Andy Goldstein es Liliana Parra, uno de sus trabajos se titula La credibilidad de lo fantástico y fue expuesta en el MAM entre septiembre y diciembre de 2006. 
te de la Comisión de Fotografía que había armado en Hijos, allí participaban Mariano Porta, Clara Rosson ${ }^{35}$, Gustavo Kun y Salvador García. El fotógrafo Marcos Adandía ${ }^{36}$ también participaba en este espacio, sacaba fotos de los escraches y de las actividades que realizaba la asociación; él pertenecía a otra generación y era militante desde los años ochenta. Más tarde (luego de finalizar su serie Arqueología de la ausencia) Lucila participó de alguno de sus talleres fotográficos.

Quieto explica que la Comisión de Fotografía nace "a partir de una propuesta de Silvana Colombo ${ }^{37}$. Estuvimos ahí un tiempo en la Comisión de Fotografía, leíamos textos, charlábamos un montón acerca de qué podíamos empezar a pensar para hacer, talleres, salíamos a sacar fotos, se armaba un encuentro, pero no se armaba concretamente un trabajo, un proyecto" ${ }^{38}$.

Ese espacio duró poco tiempo; allí hacían registros de los encuentros nacionales de Hijos. Después esta comisión derivó en la Comisión de Arte y Política, y en el

35 Clara Rosson nació en Buenos Aires, en 1976. Su padre está desaparecido. Es egresada de la Escuela de Arte Fotográfico de Avellaneda y asistió a los talleres de ensayo fotográfico de Adriana Lestido. Su serie Tarde (o temprano trabaja la ausencia de su padre, las huellas, los vestigios.

36 Marcos Adandía es autor de las series fotográficas Madres, una serie de retratos a madres de desaparecidos, Hijos, retratos a hijos de desaparecidos y Diana un ensayo fotográfico sobre los últimos días de un travesti que falleció de sida (este ensayo fue realizado en el marco de los talleres de expresión fotográfica de Adriana Lestido). Desde 2006 es editor de la revista fotográfica Dulce x Negra. Varias de sus imágenes formaron parte de la muestra colectiva Memorias en el MAM, en 2011. Y la serie Diana fue expuesta en el MAM en 2010.

37 Silvana Colombo es reportera gráfica desde hace 20 años, trabajó en la revista La Maga; fue productora del programa de fotografía "enemilímetros" emitido por Canal á, y desde hace 13 años trabaja en el diario La Nación. Ha participado de las muestras de fotoperiodismo argentino la Asociación de Reporteros Gráficos AGRA).

38 Entrevista a Lucila Quieto. Realizada por la autora, el 6 de marzo de 2013. momento cuando la asociación alquiló una casa, se dictaban talleres abiertos a la comunidad y de los que participaban muchos de sus miembros, entre ellos de fotografía. La realización de la serie Arqueología de la $A u$ sencia se dio en el marco de esas actividades y como trabajo final de la Escuela de Fotografía de Andy Goldstein.

Finalmente, para 2001 Lucila Quieto se desvinculó de Hijos debido a que, como muchos de sus compañeros, consideró que "había que abrirse de esa identidad de Hijos y pasar a formar parte de otros espacios" ${ }^{\prime 39}$. Concretamente ella fue a desarrollar tareas en la biblioteca popular que se estaba gestando en el IMPA, una de las primeras fábricas recuperadas del barrio de Almagro. $Y$ ese fue uno de los contextos de exhibición de su muestra. Lucila recuerda: "ni bien empecé a hacer las fotos, en cada actividad que hacía Hijos yo las llevaba, las colgaba, las exponía, siempre estaban ahí circulando, después en el 2001 las que expuse ahí en la escuela de Andy Goldstein y después ya se fue para afuera la muestra ${ }^{40}$.

El trabajo estuvo un tiempo en Italia porque se lo habían robado, y gracias a gestiones del Fondo Nacional de las Artes, con Tulio de Sagastizabal como director de Artes Visuales, se pudo recuperar.

Durante este período se estaban gestando también las series fotográficas de artistas como Zout, Brodsky, Dell' Oro, Ulanovsky, Pantoja, Lestido, en el marco de los juicios por la verdad, los homenajes en escuelas, las organizaciones de hijos y abuelas, y en las manifestaciones públicas. En este sentido,

39 Entrevista a Lucila Quieto, ya citada.

40 Entrevista a Lucila Quieto, ya citada. 
durante los años noventas, varios artistas vuelven del exilio y comienzan a emprender sus trabajos artísticos indagando su propia memoria personal y las consecuencias de la dictadura. A su vez, se da otro proceso dentro de la disciplina fotográfica, ya que muchos de los fotógrafos que estaban desarrollando el campo durante los años ochenta comienzan a dictar talleres de fotografía: como señala Pérez Fernández (2011), la posibilidad de comprar cámaras fotográficas determinó la existencia de una gran demanda de cursos. Juan Travnik y Eduardo Gil ${ }^{41}$ ya estaban dictando clases desde fines de los años ochenta y desde 1995 Adriana Lestido ${ }^{42}$ comienza a dictar sus talleres y clínicas.

En el marco de las clínicas de Lestido, entre 1999 y 2000, Zout comenzó a trabajar sobre su serie Desapariciones y Dell'Oro sobre Imágenes en la memoria, a partir de 1997 hasta 2000.

En ese contexto, Zout fue orientada por Lestido para continuar con su trabajo sobre los desaparecidos - una tarea que le llevó más de seis años - y que lo hizo en paralelo a

41 Entre los fotógrafos que se formaron con Eduardo Gil en su Taller de Estética Fotográfica, y luego desarrollaron series sobre la dictadura, podemos mencionar a Fernando Gutiérrez, con sus series Treintamil y Secuelas, y a Santiago Hafford, con su serie Uniformados y Orillar identidades. También se formaron allí Gabriel Díaz y Julieta Escardó, quienes desempeñan una labor particular dentro el campo fotográfico; el primero lleva adelante la Colección Fotógrafos Argentinos (desde 2007), que ha publicado libros de los fotógrafos más reconocidos en argentina; y la segunda es organizadora de las Ferias de Fotolibros de Autor (desde 2002) y curadora fotográfica en el espacio Ecléctico, entre otras actividades.

42 Adriana Lestido se formó en la escuela de Cine de Avellaneda, su esposo Guillermo "Willy" Moralli fue desaparecido por la última dictadura militar en 1978. En 1982 tomó la foto Madre e hija en Plaza de mayo, que se convirtió en ícono de la resistencia contra la dictadura. Entre los fotógrafos que se formaron con Lestido, y luego desarrollaron series sobre la dictadura, podemos mencionar a Clara Rosson, con su trabajo Tarde (o temprano), Gerardo Dell'Oro, con Imágenes de la memoria, Helen Zout, con Desapariciones, Paula Luttringer, con El matadero, Marcos Adandía, con sus series Madres e Hijos y Fernando Gutiérrez con Treintamily Secuela. su trabajo en la Cámara de Senadores de la Provincia de Buenos Aires. La serie sobre los desaparecidos le abrió diferentes puertas a su carrera profesional; Helen relata que su trabajo como curadora en el MAM fue gracias a una muestra de esa serie, en el que su jefa le propuso un cambio de trabajo y ella logró el pase al MAM ${ }^{43}$.

Por su parte, la serie Buena Memoria ${ }^{44}$ de Marcelo Brodsky surge a la vuelta de su exilio, hacia 1996, cuando se estaban gestando actos de homenaje, colocación de placas y recordatorios en distintas unidades académicas, puntualmente en su caso en el Colegio Nacional Buenos Aires, en el cual se creó un evento llamado Puente de la Memoria para recordar a los desaparecidos de esa casa de estudios. En ese momento Brodsky intervino la fotografía escolar para colgarla en el colegio, y junto a otros compañeros crearon un monumento para instalar en la escuela. Ese acto fue organizado por un grupo de ex alumnos, que luego sintetizaron esa iniciativa en la propuesta de la creación del Parque de la Memoria en la costanera norte de Buenos Aires, y presentaron a organismos de derechos humanos la idea de crear un monumento a los desaparecidos a la vera del río. Para ello, en julio de 1998, se creó la asociación civil Buena memoria, que encabezó los debates para la creación del Parque. Este fue inaugurado el 7 de noviembre de 2007 y desde ese momento Brodsky integra el Consejo del Parque de la Memoria junto a representantes de los

43 Según la anécdota, cuando la vicegobernadora vio la muestra fotográfica que se había montado en la Legislatura en 2008, le dijo si quería un aumento de sueldo o de categoría, y Zout le pidió un pase a una tarea de curaduría. Debido a esto fue trasladada al MAM.

44 Analizada en Larralde Armas (2014a). 
organismos que lo componen ${ }^{45}$. Allí colabora en las gestiones sobre el aspecto artístico y cultural dentro del área de artes visuales ${ }^{46}$, para la instalación de muestras, esculturas y concursos artísticos, entre otros.

Desde la asociación Buena memoria, Brodsky ha estado presente en los debates sobre la ESMA y en diversas tareas dentro de los derechos humanos. Marcelo Brodsky señala que "en ese momento, yo participé directamente de esa discusión y de esa iniciativa porque en la ESMA estuvo mi hermano. Yo consideré necesario realizar una publicación, de lo que habíamos discutido sobre ese lugar, bajarla a un libro, son fotos y textos que aportan al debate" ${ }^{\prime 4}$.

Así fue como se realizó la edición del libro Memoria en construcción (2005), que reúne debates, ensayos y reflexiones, obras de artistas plásticos y fotografías, entre ellas las de Víctor Basterra (que abren el libro), Helen Zout, Juan Travnik, Fernando Gutiérrez, Martín Kovensky, Res, Marcelo Grosman, Inés Ulanovsky, Julio Pantoja ${ }^{48}$, Paula Luttringer, Lucila Quieto, Óscar Bony, en-

45 El Consejo de Gestión del Parque de la Memoria está integrado por Abuelas de la Plaza de Mayo, Madres de Plaza de Mayo-línea fundadora, Familiares de Desaparecidos y Detenidos por razones Políticas, la Fundación Memoria Histórica y Social Argentina, el Centro de Estudios Legales y Sociales, la Asociación Civil Buena Memoria, la Asamblea Permanente por los Derechos Humanos, la Liga Argentina por los Derechos del Hombre (LADH), el Movimiento Ecuménico por los Derechos del Hombre (MEDH) y el Servicio Paz y Justicia (Serpaj).

46 Coordinada por Florencia Battiti.

47 Entrevista a Marcelo Brodsky. Realizada por la autora el día 8 de mayo de 2013.

48 Julio Pantoja (nacido Buenos Aires, en 1961) realizó su serie fotográfica Los hijos. Tucumán 20 años después en 1998. Ha expuesto en el Centro Cultural Recoleta, con curadurías de Ana Longoni y Julieta Esacardó. Es curador de la galería Fotograma y director de la Bienal Argentina de Fotografía Documental. Es coautor del libro Body politics, políticas del cuerpo en la fotografía latinoamericana con Marcelo Brodsky. tre otros muchos artistas plásticos. Marcelo Brodsky se desempeñó como curador para este libro, eligiendo las obras que también fueron instaladas en el Centro Cultural Recoleta para el $30^{\mathrm{a}}$ aniversario del golpe. Brodsky considera que "la gestión cultural ligada al arte hoy en día es absolutamente necesaria"49, y la parte de su obra que tiene que ver con los derechos humanos le exige un contacto con organismos, espacios públicos e instituciones que él entiende como una militancia:

[...] pero es una militancia compatible con otra serie de actividades, no es una militancia tradicional como si fuera un político, es el arte el que exige gestión, el arte que exige militancia. Para poder suceder y para poder ser en el espacio público, o en una galería, o en un museo, o en el circuito internacional - del cual yo participo activamente- tengo que tener toda esa actividad de gestión ${ }^{50}$.

Con la concreción de este sitio ya se estaba abriendo otra etapa para los trabajos de la memoria, ya que a partir de 2004 la recuperación de ex centros clandestinos de detención como lugares de memoria promueve una nueva gestión que hace un uso privilegiado de los dispositivos artísticos (Battiti, 2013), a la vez que abre otro abanico de temáticas en relación con los CCD que son abordados por muchos fotógrafos. Por ejemplo, en las series fotográficas de Paula Luttringer (con El lamento de los muros), Diego Aráoz (con Santa Lucía, arqueología de la violencia), Inés Ulanovsky (con ESMA), entre otros. También es al inicio de esta década cuando se inaugura el MAM en 2002, y

49 Entrevista a Marcelo Brodsky, ya citada.

50 Entrevista a Marcelo Brodsky, ya citada. 
se instalan las muestras de estos fotógrafos y de artistas plásticos sobre la temática.

A su vez, durante esta etapa y en el marco de las leyes reparatorias para víctimas del terrorismo de estado, muchos hijos de desaparecidos comienzan a trabajar en la administración pública $^{51}$, sobre todo en instituciones dedicadas a la problemática de la memoria. Por ejemplo, Lucila Quieto trabaja en el predio de la ex ESMA, a partir de que en 2008 el Archivo Nacional de la Memoria le cediera un espacio físico a la fototeca del Argra: allí se desempeña Quieto hasta la actualidad. Respecto a esta cuestión, menciona: "me volvió a reconectar con un montón de proyectos ${ }^{52}$ y de laburos que tenían que ver con la militancia que yo tenía en Hijos, porque me reencontré con ex compañeros de Hijos y que ahora compartimos este trabajo". Lucila es parte del equipo de la fototeca del Argra desde 2007 junto a Inés Ulanovsky ${ }^{53}$; las dos realizaron la muestra Archivos incompletos ${ }^{54}$, que se trataba de más de seiscientas imágenes originales y notas de prensa producidas durante 1975 por la Policía Federal —de acuerdo con el sello y descripciones que se

51 Según lo indica la Ley Nํ 13. 745, Res. 318/09.

52 A raíz de esto, algunos ex integrantes de HIJOS, como colectivo crearon el proyecto "Tesoros", se trata de una web con fotos y videos, sobre objetos valiosos para la recordación de sus padres. Está disponible en internet desde abril de 2013 y cuenta con apoyo del Fondo Nacional de las Artes. Ver: http://www.proyectotesoros.org/ proyecto.html.

53 Inés Ulanovsky (nació en 1977, en Buenos Aires), sus series fotográficas más destacadas son "Fotos Tuyas"; que trabaja el lugar que ocupan las fotos de los desaparecidos en el seno del hogar, y la serie "ESMA" que fue ganadora del premio FELIFA-DOT, de la Feria de fotolibros de autor en el 2010, aborda diferentes paisajes del predio de la ESMA en la actualidad. Para un análisis de la serie "Fotos Tuyas" ver Fortuny (2011).

54 Exhibida en la Tercera Bienal de Fotografía documental de la Argentina, en Tucumán, año 2008. Además de en las ciudades de Trelew y Córdoba. leen al dorso de las imágenes - , que luego eran enviadas a los diarios La Razón, Tiempo Argentino y El Cronista Comercial, para su utilización. Aparecieron clasificadas con las denominaciones Argentina: terrorismo, subversión o extremistas, muestra que incluye collages e intervenciones fotográficas, técnica que continuó desarrollando en el marco de seminarios y clínicas con Julieta Escardó ${ }^{55}$ y luego con Tulio Sagastizabal, quien refiere lo siguiente:, "me cambió totalmente porque yo venía de un sector de formación más de fotografía, y con él fue aprender otro lenguaje, lo que es la pintura, el dibujo, la escultura, otra forma de pensar, otra forma de ver la imagen, de trabajarla, de hablar del trabajo mismo"56. De hecho, su último trabajo Filiaciones ${ }^{57}$ se trata de una obra más ligada a la plástica, en los que incluye collages, fotografías y dibujos.

\section{LOS TEMAS DE LAS OBRAS}

Así como las relaciones y la trama social tejen las dinámicas del campo fotográfico, los vínculos y las relaciones posibilitan la creación artística. Puntualmente, en las cuatro trayectorias que analizamos: Brodsky, Zout, Dell'Oro y Quieto, se da un profundo trabajo con ex alumnos, víctimas, testigos, compañeros de militancia e hijos de desaparecidos. Como consecuencia, hay una comunidad que participa en la construcción del recuerdo, así como en su creación

55 Julieta Escardo, es fotógrafa, editora, curadora y docente. Es codirectora de la Editorial La Luminosa y curadora de la fotografía en el Espacio Ecléctico, Buenos Aires. Durante el año 2002 expuso las fotografías de Quieto, en el 2006 la serie de Clara Rosson, además de innumerables muestras fotográficas.

56 Entrevista a Lucila Quieto, ya citada.

57 Muestra que fue inaugurada en el Centro Cultural Haroldo Conti, de abril a junio de 2013. Para un análisis sobre esta serie ver Blejmar (2013). 
artística. Este tipo de proceso creativo conlleva la relación con un grupo social determinado y posibilita lazos que se construyen entre el fotógrafo y los fotografiados, cuestión que se convierte en la esencia de este tipo de práctica artística. En estos casos los temas fotográficos tienen que ver directamente con las experiencias de vida de los fotógrafos. Aquí la rememoración, tanto como el acto de creación artística, necesitan de la existencia de una "comunidad sentimental" (Déotte, 2000), o de una "comunidad afectiva" (Halbwachs, 2004, p. 33), que posibiliten la construcción y transmisión de estos significados sobre el pasado.

En este sentido, cada fotógrafo se relaciona directamente con su experiencia y desde allí se vincula con la temática que quiere retratar. Por ejemplo, en el caso de Zout, cuando debe pasar a la clandestinidad durante la dictadura, se dan los momentos claves en los que nace la necesidad de buscar otro lenguaje no verbal para expresar y comprender lo que estaba sucediendo, que también se asocian con sus intereses sociales, militantes y la forma de trabajar con los sujetos. De hecho, para Zout la concreción de un retrato, implica siempre la realización de entrevistas y varios encuentros con los fotografiados, "siempre hago fotos en las que cuales se establezca un vínculo con el fotografiado, es como un modo de vivir, ya más que de fotografiar" ${ }^{\prime 2}$, reflexiona. Esta necesidad de comprender se observa en el tipo de obra que realizó Helen, un trabajo que le ha llevado más de seis años y que afronta una variedad de huellas del accionar de la dictadura. Se modo que en el conjunto de su obra hay imágenes del reconocimiento

58 Entrevista a Helen Zout, ya citada. de predios junto a testigos, pericias con el Equipo de Antropología Forense, centros clandestinos de detención, aviones de centros náuticos, peritajes policiales y retratos a hijos de desaparecidos, sobrevivientes y madres. Ella considera que la producción de la serie Huellas fue "un trabajo de acompañamiento, creo que entre todos nos fuimos acompañando, mucha gente me acompañó y yo acompañé a mucha gente ${ }^{\prime \prime 59}$.

Zout relata que ella iba a la Cámara Federal a escuchar los testimonios “y esperaba a la salida a las personas y les proponía hacer este trabajo" ${ }^{\prime 60}$. Por ejemplo, con el caso de la foto a Julio López ${ }^{61}$, que hoy se ha convertido en un símbolo ${ }^{62}$ de la lucha por su aparición, le demandó varios encuentros y charlas,

[...] a López lo conocí a través de Nilda Eloy y de las Abuelas de La Plata. Yo lo conocí en la sede de Abuelas y ahí le propuse el trabajo, él aceptó enseguida. Tuvimos muchísima buena onda, porque él es como o no hablaba o se hablaba todo, cuando encontraba un canal para hablar con él que él se sintiera cómodo era increíble su entrega. Lo retraté varias veces, pero como que es algo que va creciendo el vínculo. A

59 Entrevista a Helen Zout, ya citada.

60 Entrevista a Helen Zout, ya citada.

61 Julio López era un testigo en la causa al represor Miguel Etchecolaz, fue secuestrado y desaparecido en el 2006, poco después de brindar testimonio, hasta el día de hoy no existen noticias sobre su paradero.

62 La imagen de Julio López, realizada en stencil, se instala en las paredes de la ciudad y de la universidad, sobre todo para el aniversario de su desaparición, todos los 17 de septiembre. Helen Zout siente "un orgullo, porque me hace sentir que lo que sentí como intuitivo, finalmente se impuso como algo significativo en la sociedad, en la memoria y en la historia. Que representa a López y a los desaparecidos". Entrevista a Helen Zout, ya citada. 
veces no, la primera vez sacás la mejor foto, pero en general para mí los mejores retratos fueron los que yo construí en un vínculo que crece. Y bueno, lo retraté varias veces, y creo que la última vez fue el mejor retrato ${ }^{63}$.

La conformación de la serie la llevó a realizar entrevistas y retratos en el exterior a mujeres sobrevivientes y exiliadas, como es el caso de la foto de Marta, que prefiere reservarse su apellido. Helen relata que en sus viajes se encontraba con "gente que nunca había hablado del tema"64, con algunos lograba una imagen y con otros no, pero considera que siempre con

\section{[...] una persona que calló durante} 25 años, tenés que tener muy buena vinculación de una con esa persona, porque yo la conocía en tres días. La llamaba e iba a la casa o después me reunía, no es fácil, para nadie, ni para esa persona ni para mí, y sin embargo logré muy buena vinculación con muchas personas, que después muchos de esos vínculos los continué ${ }^{65}$.

"La obra suscita encuentros y da citas, administra su propia temporalidad" (Bourriaud, 2008, p. 32). Y así es, estas citas y encuentros, individuales y colectivos son parte de los procesos artísticos de los cuatro fotógrafos. Una estrategia similar es la de Marcelo Brodsky: el fotógrafo citó a sus ex compañeros del Colegio Nacional y les solicitó que llevaran algún objeto con el que se identificaran, y en el marco de una reunión de reencuentro tomó las fotos. A quienes no

\footnotetext{
63 Entrevista a Helen Zout, ya citada.

64 Entrevista a Helen Zout, ya citada.

65 Entrevista a Helen Zout, ya citada.
}

asistieron los retrató luego en sus casas o ámbitos de trabajo.

Por su parte, Dell'Oro articuló los registros fotográficos familiares que había tomado su padre, también fotógrafo, con una indagación inicial en el predio de Arana, donde metafóricamente apela a sus emociones al saber que allí fue asesinada su hermana; cuestión de la que se enteró a través del testimonio de Julio López en los Juicios por la Verdad en 1999, en La Plata. En esta parte de la serie Imágenes en la memoria registra las ramas peladas de los árboles, en una composición en blanco y negro, movida y desenfocada. La muestra se compone también con una serie de retratos a su sobrina. Sobre su proceso creativo, Dell'Oro explicó en una nota periodística:

[...] todo esto empieza como un intento de ensayo fotográfico con una chica hija de desaparecidos, y al mismo tiempo le sacaba a Mariana, hasta que me di cuenta de que tenía que ser a Mariana. Ponía distancia, no sabía bien qué tan afuera o qué tan adentro estaba de su historia, cuál era mi lugar. Quedó ahí en un cajón hasta el juicio (contra Etchecolatz). La condena cosió la historia, ató las partes. Y el secuestro de López me dejó en un lugar de angustia que no podía resolver. Algo tenía que hacer, y fue esto: los ojos de Mariana, los ojos de Patricia, las fotos familiares del '76 y del'96 en el álbum familiar, aparecieron los viejos negativos de mi papá de fotos que le sacó a Patricia, y el relato de López que me traía una imagen que yo no quería. Patricia era la hija desaparecida de mi viejo, era la hermana desaparecida nuestra, eran los padres 
que Mariana nunca había conocido. Cuando López me cuenta, me cae la ficha de que Patricia es la madre que se perdió de criar a una hija, esa foto que me faltaba me la da López, es una imagen relatada y guardada en la memoria (Meyer, 28 de abril de 2008, s. p.).

Sus indagaciones comienzan en un momento de la historia argentina en el que el juzgamiento a los represores no era posible, durante 1996, por lo que transita esa indeterminación en la primer etapa de la obra a través de las fotos a los árboles. La creación se detiene un tiempo y es retomada a partir del juicio a Etchecolatz, en 2006. Este marco crea una sutura familiar que intenta abordarse a través de las fotografías a su sobrina, pero a la vez crea una nueva herida que es la segunda desaparición de Julio López, cuestión que trabaja en esta serie, así como en su trabajo Jorge Julio López. Desaparecido en Democracia, que presenta fotografías tomadas durante distintas acciones políticas y artísticas realizadas en reclamo por su aparición con vida en La Plata.

Lucila Quieto también abre la posibilidad de encuentro con gente de su generación, para crear su serie fotográfica. A través de una invitación, escrita en un cartelito que pegó en la sede de Hijos, convocó a retratarse y lograr la imagen imposible, con un mensaje que decía: "Si querés tener la foto que siempre soñaste y nunca pudíste tener, ahora es tu oportunidad, no te la pierdas. Llamame" (Longoni, 2010, p. 276). Una necesidad que parecía muy suya de pronto se manifestó como una necesidad dentro del grupo de hijos. Actualmente, su arte y militancia giran en torno a la temática de la identidad, la ausencia, los restos, el duelo.

\section{Conclusiones}

A lo largo de estas páginas, ha sido posible reconstruir la conformación de un campo artístico, a través del dispositivo fotográfico. Metodológicamente el seguimiento de estas cuatro trayectorias nos permite entender un sistema de relaciones sociales entre artistas-militantes y su objetivo de instalar su producción y su búsqueda de memoria. De modo que podemos concebir estas producciones como dispositivos pensantes ${ }^{66}$ (Barei, 2005, p. 22) y como testimonios visuales de lo ocurrido. En este aspecto, las fotografías logran instalarse en un lugar de intercambio entre lo individual y lo colectivo, en un esfuerzo siempre presente de un trabajo de memoria. Y el MAM se sitúa como un espacio de circulación privilegiado, para este tipo de arte y temáticas, dentro de la amplia red de espacios artísticos y militantes que fueron estableciéndose en esta última década en Argentina.

\section{Anexo trayectorias Marcelo Brodsky}

Brodsky nació en Buenos Aires en 1954 y vivió allí hasta que se tuvo que exiliar, primero a Brasil y luego a Barcelona en 1977, cuando los militares intentaron secuestrarlo. Su hermano, Fernando, y su mejor

66 Si tal como propone Barei entendemos al "texto artístico como un dispositivo pensante: su memoria carece de homogeneidad interna, trabaja a partir de discursos que recupera y transforma creativamente y sus sentidos dependen de la variación de los contextos culturales en los que el texto se semantiza y de las conciencias históricas con las que dialoga [...]", podremos pensar "las articulaciones entre arte y fenómenos extra-artísticos en tanto relaciones que incluyen las experiencias histórico-culturales de productores y lectores y su capacidad activa para crear nuevos textos y borrar otros: dispositivos de memoria (como creación) y de olvido (como desplazamiento), constituyen el mecanismo impulsor de las transformaciones culturales" (Barei, 2005, p. 22). 
amigo, Martín, fueron secuestrados por la dictadura, entre otros compañeros de la escuela.

Estudió en el Centro Internacional de Fotografía, que dirigía Manuel Esclusa. Durante los años ochenta estuvo en Argentina intermitentemente y en una de esas ocasiones expuso en la Fotogralería Omega, en 1987, se trataba de la serie Aperturas, que luego también fue expuesta en Buenos Aires. En los años noventa vuelve a Argentina y elabora su trabajo Buena Memoria, en el Colegio Nacional Buenos Aires.

Este grupo de ex alumnos creo la propuesta de la construcción del Parque de la Memoria y para ello en fundó la asociación civil Buena Memoria en 1998. El parque fue inaugurado el 7 de noviembre de 2007, y desde ese momento Brodsky integra el Consejo del Parque de la Memoria. Desde la asociación, Brodsky ha estado presente en los debates sobre la ESMA y en diversas tareas dentro de los derechos humanos. Además, editó el libro Memoria en Construcción (2005), que contiene debates, ensayos y reflexiones, obras de artistas plásticos y fotografías. Entre los trabajos fotográficos que editó en formato libro se encuentran Buena memoria, Memoria ec Construcción, Nexo y Memory works, todas obras en torno a la memoria, las huellas y la palabra.

\section{Gerardo Dell' Oro}

Nació en La Plata en 1966. Cuando secuestraron a su hermana Patricia, él tenía 10 años. Comenzó su aprendizaje fotográfico en la Escuela Municipal de Avellaneda en 1984. Entre 1997 y 2000 integró el grupo de taller de ensayo fotográfico de Adriana Lestido; en ese marco comenzó su serie sobre los árboles en el predio de Arana, que es parte de su muestra Imágenes en la memoria. Tomó esas fotos en 1999 cuando su padre, también fotógrafo, presentó el caso de Patricia en el Juicio por la Verdad, en La Plata. Esta muestra fue inaugurada en marzo de 2008, en el Museo de Arte y Memoria de La Plata; la misma se trató de su primera exposición individual. Actualmente, trabaja como fotoperiodista en medios gráficos como La Maga, La Prensa y el diario Clarín. Ha participado de la Feria de Libros de Fotos de Autor que organiza el Espacio Ecléctico. Algunos de sus libros han sido editados en Argentina y Francia: Malvinas, Imágenes en la memoria y Desaparecido en democracia.

En 2001, 2003 y 2005 participó en las muestras colectivas Sobre tablas, Teatro BA y 20 años de la Fotogalería, en la FotoGalería del Teatro San Martín. Ha expuesto en las muestras anuales de la Asociación de Reporteros Gráficos.

\section{Helen Zout}

Helen Zout nació en Carcarañá, provincia de Santa Fé, y se radicó en La Plata para cursar sus estudios universitarios en antropología. En esa época comenzó a militar en la Juventud Universitaria Peronista. Cuando llegó la dictadura comenzó a ser perseguida, lo que la llevó a vivir en la clandestinidad. Algunos de sus compañeros fueron desaparecidos ${ }^{67}$ y ella vivió escondida junto a su marido, primero en Mar del Plata y luego en Buenos Aires, porque no tenía pasaporte. Entre 1979 y 1980 pudo regresar a La

\footnotetext{
67 Entre ellos la fotógrafa Paula Luttinger, que sobrevivió y luego se exilio en Francia. Su serie El lamento de los muros fue expuesta en el MAM, de diciembre de 2005 a marzo de 2006.
} 
Plata. Cuando estaba en la clandestinidad, tomó cursos con el fotógrafo Juan Travnik.

A su regreso a La Plata, funda junto a su ex marido (Ataúlfo Pérez Aznar) la primera fotogalería especializada e independiente de la región; el 10 de octubre de 1980; luego crean el Núcleo de Autores Fotográficos (NAF), en mayo de 1984. Se trató de un grupo de reunión, discusión y debate de fotógrafos argentinos. El NAF funcionó hasta 1988, y organizó las Jornadas de Fotografía Buenos Aires, La Plata. En 1989 obtuvo una Beca del Fondo Nacional de las Artes y desarrolló diferentes series fotográficas sobre los niños con sida en el Hospital de Niños de La Plata, grupos de inmigrantes e indígenas de la provincia de Misiones y hospitales neuropsiquiátricos; además de trabajar como reportera gráfica del Diario La Razón (1983- 1986). En el marco de una de las clínicas dictadas por Adriana Lestido, entre 1999 2000, logró su trabajo sobre los desaparecidos.

Luego en 2002, obtuvo una Beca John Simon Guggenheim de Estados Unidos, para continuar con sus trabajos fotográficos. En 2004 participó como curadora invitada en el MAM, con la muestra Fotos robadas, fotos recuperadas, y en 2005 expuso su muestra sobre la dictadura, que en ese momento llevó el título Huellas.

Zout trabajó como fotógrafa 18 años en la Cámara de Senadores de la Provincia de Buenos Aires, y en el 2008 montó su muestra en la Legislatura, gracias a esa exhibición logró un pase al Museo de Arte y Memoria, para desarrollar tareas de curaduría.

De modo que, Helen Zout se desarrolló como curadora fotográfica y fotógrafa del
MAM, durante el período 2008-2012. A su vez, ese tiempo trabajó sobre la serie Invisible, sobre los chicos que viven en la calle. Actualmente continúa como fotógrafa de la CPM. En 2011 le otorgaron el premio a la obra y la trayectoria de la Secretaría de Cultura de la Nación y 2012, el Gran Premio Adquisición del Fondo Nacional de las Artes.

\section{Lucila Quieto}

Carlos Quieto, militante de montoneros y papá de Lucila, fue secuestrado el 20 de agosto de 1976, cuando Lucila tan solo tenía 5 meses de gestación; por lo que nunca pudo conocer a su padre. Esta experiencia marcó los primeros años de su vida. El encuentro de la fotografía y de la militancia se dieron en simultáneo durante la adolescencia. Fue para 1995 cuando empezó a militar en Hijos, que la política, las luchas sociales y el arte encontraron un cauce. Por un lado, Lucila cursaba sus estudios en fotografía en la Escuela de Fotografía Creativa de Andy Goldstein (entre 1996 y 2001); por el otro lado, participaba en escraches, registros de encuentros y de un comité de fotografía dentro de Hijos, organización de la que formó parte hasta 2001. En este marco realizó la serie Arqueología de la ausencia, que fue expuesta en el MAM en 2004.

La fotógrafa continuó formándose; con Julieta Escardó y luego con Tulio Sagastizabal realizó clínicas durante casi tres años. En 2007, nuevamente fue convocada por el MAM y expuso unos collages en el marco de una muestra colectiva sobre Oesterheld. En el mismo sentido, su último trabajo Filiaciones, se trata de una obra más ligada a la plástica, los collages con fotografías y dibujos. 
A nivel laboral, estuvo trabajando en la fototeca del Argra desde 2007, junto a Inés Ulanosky, juntas realizaron la muestra $A r-$ chivos Incompletos. Durante 2008, la fototeca del Argra comenzó a funcionar en el edificio de la ex ESMA, en un espacio cedido por el Archivo Nacional de la Memoria, allí trabaja actualmente. También ha realizado varias exposiciones en el país y en el exterior.

\section{REFERENCIAS}

Barei, S. N. (2005). Políticas de la memoria: texto artístico y lectura crítica del poder. Revista Estudios del Centro de Estudios Avanzados, (16).

Battiti, F. (2013). Exposiciones como forma de discurso. Algunas consideraciones sobre las muestras de artes visuales en los espacios de memoria en Argentina. Revista de Instituciones, Ideas y Mercados, (59), 181-190.

Bautista Duizeide, J. Fotomundo (noviembre, 2009). Museo de Arte y Memoria de La Plata. Un espacio para la fotografía. Fotomundo, (491).

Blejmar, J. (2013). La Argentina en pedazos: los collages fotográficos de Lucila Quieto. En J. Blejmar, N. Fortuny y L. I. García (Eds.), Instantáneas de la memoria. Fotografía y dictadura en Argentina y América Latina (pp. 173- 193). Buenos Aires: Libraria.

Bourdieu, P. (1990). Sociología y Cultura. México, D. F.: Grijalbo.

Bourdieu, P. (1997). La ilusión biográfica. En Razones prácticas, sobre la teoría de la acción (pp. 74- 83) Barcelona: Anagrama.

Bourdieu, P. (2000). Cosas dichas. Barcelona: Gedisa.
Bourdieu, P. (2003). La fotografía un arte intermedio. Ensayo sobre los usos sociales de la fotografía. Barcelona: Gustavo Gil Editor.

Bourdieu, P. y Wacquant, L. J. D. (1995). Respuestas por una Antropología reflexiva. México, D. F.: Grijalbo.

Bourriaud, N. (2008). Estética relacional. Buenos Aires: Adriana Hidalgo Editora.

Chartier, R. (1990. La historia cultural redefinida: prácticas, representaciones, apropiaciones. Punto de Vista, (38), 43- 48.

Chartier, R. (1992). El mundo como representación. Historia cultural entre práctica y representación. Madrid: Gedisa.

Chauviré, C. y Olivier, F. (2008). El vocabulario de Bourdieu. Buenos Aires: Atuel.

Déotte, Jean Louis (2000). El arte en la época de la desaparición. En N. Richard (Ed.), Políticas y estéticas de la memoria (pp. 148-163). Providencia, Santiago: Cuarto Propio.

Fortuny, N. (2009). ¿Dónde están? La espacialidad fotográfica, el cuerpo y la memoria en una serie temprana de Res. Revista Question, 1(23). Recuperado de http://perio.unlp.edu.ar/ojs/index.php/ question/article/viewArticle/803

Fortuny, N. (2011). Cajas chinas. La foto dentro de la foto o la foto como cosa. Revista Chilena de Antropología Visual, (17). Recuperado de http://www.antro pologiavisual.cl/img17/imprimir/for tuny_imp.pdf

Fortuny, N. (diciembre, 2011). Paula Luttringer: "La incertidumbre de no saber". Boca de Sapo, XII(11).

Gamarnik, C. (2013). Imágenes contra la dictadura: la historia de la primera muestra de periodismo gráfico argentino. En J. Blejmar, N. Fortuny y L. I. García (Eds.), Instantáneas de la memoria. 
Fotografía y dictadura en Argentina $y$ América Latina. Buenos Aires: Editorial Libraria. Pág. 69- 92.

Halbwachs, M. (2004). La memoria colectiva. Zaragoza: Prensas Universitarias de Zaragoza.

Jelin, E. (2002). Los trabajos de la memoria. Buenos Aires: Siglo XXI.

Larralde Armas, F. (2013). Lucila Quieto, hijos atravesando el paisaje: imágenes para construir el recuerdo añorado. Revista Aletheia, 4(7). Recuperadod e http:// www.aletheia.fahce.unlp.edu.ar/numeros/aletheia-7/articulos/lucila-quieto-hijos-atravesando-el-paisaje-imagenes-para-construir-el-recuerdo-anorado

Larralde Armas, F. (2014a). Imágenes como epitafios sustitutos: en una serie de Marcelo Brodsky. Revista Argus-a Artes \& Humanidades, 3(11). Recuperado de http:// www.argus-a.com.ar/pdfs/image nes-como-epitafios-sustitutos.pdf

Larralde Armas, F. (2014b). Políticas de la memoria, a propósito de su vigésimo aniversario en la ciudad de La Plata (Argentina): la configuración de un campo y sus prácticas. Revista mexicana de Ciencias Políticas y Sociales, 59(221). Recuperado de http://www.revistas. unam.mx/index.php/rmspys/article/ view/47829/43075

Litvin , L. (22 de octubre, 2008). El sentido de mis fotos es acercarme a la verdad. Tiempo Argentino.

Longoni,. (2010). Apenas, nada menos (en torno a Arqueología de la Ausencia, de Lucila Quieto). En . Birle et al. (Eds.), Memorias Urbanas en diálogo: Berlin y Buenos Aires (pp. 273-287). Buenos Aires: Buenos Libros Ediciones. Núcleo de Autores Fotográficos (s. f.). http:// 30naf.wordpress.com
Pérez Fernandez, S. (2011). Apuntes sobre fotografía argentina a fin de siglo: hacia la construcción de un mercado". En S. Pérez Fernández y Gamarnik. Artículos de investigación sobre fotografía (pp. 7-48). Montevideo: Ediciones CMDF, Centro de Fotografía de Montevideo.

Meyer, A. (28 de abril de 2008). La memoria de las imágenes. El País. Recuperado el 27 de enero de 2015, de www.pagina12. com.ar/diario/elpais/ 1-103205-2008-0428.html

Usubiaga, V. (2012). Imágenes inestables. Artes visuales, dictadura y democracia en Buenos Aires. Buenos Aires: Edhasa.

\section{Sitios web}

Fotógrafa Helen Zout (s. f.). Recuperado el 1 de agosto de 2014, de http://www.helenzout.com.ar/.

Ausencias. Exposición fotográfica Gustavo Germano (28 de agosto de 2012). Recuperado el 1 de agosto de 2014, de http:// ausencias-gustavogermano.blogspot. com.ar/

RES. Recuperado el 1 de agosto de 2014, de http://www.resh.com.ar/

Museo de Arte y Memoria de la Comisión Provincial por la Memoria (s. f.). Recuperado el 2 de febrero, de http://www. comisionporlamemoria.org/museode arteymemoria/

Núcleo de Autores Fotográficos (NAF). Recuperado el 4 de febrero de 2014, de http://30naf.wordpress.com/

Proyecto Tesoros (s. f.). Recuperado el 7 de febrero de 2014, dehttp://www.proyectotesoros.org/proyecto.html 